Khalid Hussain K. Moukali

Assistant Professor and Dean of Faculty of Education

Jazan University, Jazan, Kingdom of Saudi Arabia

kmoukali@jazanu.edu.sa

Muhammad Noman Saeed

Lecturer Deanship of eLearning \& Distance Learning

Jazan University, Jazan, Kingdom of Saudi Arabia

msaeed@jazanu.edu.sa

\title{
AN OVERVIEW OF THE INTERACTIVE LEARNING MANAGEMENT SYSTEM OF JAZAN UNIVERSITY, SAUDI ARABIA
}

\begin{abstract}
The effective utilisation of technology provides a more collaborative environment to improve the traditional distance learning. Moreover, it has invigorated a new era of discussion from a range of participants including online learners, learning sources, and eLearning managers. The Learning Management System (LMS) is defined as a hub for handling the overall learning framework in Distance/eLearning education. The system is not only capable of covering the Learning process to the Learners but also acts as a bridge between Learners, Instructors, and learning resources. This study describes the key characteristics and functions of the newly deployed LMS at Jazan University called JUMP (Jazan University Multi-Platforms) with an overview of the previous system, JUSUR, which is an Arabic word, meaning Bridges. The emphasis of deploying JUMP as a new LMS by supplanting the former system is to establish a unified eLearning platform for Jazan.
\end{abstract}

Keywords: Electronic Learning; Learning Management System; JUMP; JUSUR; Jazan University; Distance Learning.

\section{INTRODUCTION}

Learning is a process of acquiring new knowledge or strengthening the present one through improved learning pedagogies, and the latest technical tools and learning management systems. The entire process of knowledge acquisition in a learner's behaviour produces changes based on the learning steps and, therefore, should be relatively permanent (Schacter D.L., Gilbert D.T., and Wegner D.M., 2011). Moreover, the terms E-Learning, eLearning, and e-Learning are commonly interchangeable for acquiring on-demand learning techniques through the computer, handheld devices having Internet-enabled features, etc.

Due to the immense progression in Information technology and the implementation of IT in learning and education, many systems have evolved which provide eLearning and Distance education. Therefore, using technology, the traditional Distance education has transitioned from e-learning to mobile learning due to the ubiquitous influence of the Internet, as well as accelerated progress in Information and Communication Technology (ICT) and recent developments in learning technology (Arshad Muhammad, Muhammad Noman Saeed, 2014). These systems are designed not only to virtualise the classroom-based environment but also develop in a way to present the effective use of Information Technology. Using these systems, a learner can get a collaborative experience for utilising augmented learning through online teaching using digital contents and various devices.

The effective learning phase using an eLearning tool is dependent on the effective usability and utilisation of the Learning Management System which is used for managing the content, tracking learning activities, assessment, etc. Consequently, the LMS has always played a crucial role in the eLearning environment. In addition, it is also required to integrate the LMS with other systems of an academic environment to fully virtualise and present the 
interactive system to the Learner and Instructor. Ideally, the LMS is responsible not only to provide the eLearning courses but also manage the overall academic activities of the Learner as well.

There are currently many types of Learning Management Systems available for administrating and managing the Virtual Learning Environment, and are used by academics and other organisations. The LMS can be divided in several ways like Open Source or Commercial products, Educational or Corporate systems, Hosted or Cloud based, Integrated or Stand-alone, etc. The blackboard considers the leading provider of the LMS services with a market share of $41 \%$ higher education through e-learning based on a 2013 survey followed by the 23\% deployment of the Open Source Moodle LMS (Kenneth C. Green, Cynthia Golden, 2013).

Essentially, all LMS's provide eLearning courses through collaborative or stand-alone learning through numerous content formats and components, including Media Lectures, Online Classes, Forums, Assessment, etc. Therefore, this sort of learning can also be termed as Augmented Learning where an individual adopts the learning steps which are personalised to its natural environment into augmented digital libraries (Doswell, Jayfus T, 2006). Such libraries or content include, but are not limited to texts, images, videos, audios, etc.

The Deanship of eLearning and Distance Learning of Jazan University conducted a study under the approved research project titled "KAP (Knowledge, Awareness, \& Practices) Study for Evaluating eLearning and Distance Learning Programmes in Higher Education". The project was awarded under the 06th Scientific Research Grant through the Ministry of Higher Education, Deanship of Scientific Research, Jazan University, Kingdom of Saudi Arabia. The aim of the study and, particularly, this paper is to present the newly deployed LMS (JUMP) and compare it with the old LMS (JUSUR) by analysing the features and functionality provided by each LMS for online learning at Jazan University. This article intends to present the Learning Management System being utilised at Jazan University with the comparative analysis of their technical and functional features.

\section{LEARNING PLATFORM AT JAZAN UNIVERSITY}

Jazan University is leading the development of Higher Education in Saudi Arabia by seeking academic excellence in innovation in community development and service. Currently, Jazan University is offering online learning programmes to its students through the Deanship of eLearning and Distance Learning in various disciplines. These Online programmes are divided in two (02) main streams, i.e., eLearning and Distance Learning. Those students who are off-campus lie in the distance learning category, and the e-learning category is for the oncampus students who are using the learning platform as a Blended learning method for their course of study during their stay at the university or from outside the campus. Initially, all programmes, including distance learning or eLearning, were offered using the JUSUR learning management system which is centrally deployed and is administrated by the National Centre for eLearning and Distance learning (NCeL). However, keeping view of a number of students and associated administrative factors, a campus-based LMS (JUMP) was proposed and deployed which is solely managed by the university management staff. A brief difference between the JUSUR and JUMP systems is presented in Table-1 as below. 
Features Comparison of JUSUR and JUMP System

\begin{tabular}{|c|c|c|c|}
\hline \multicolumn{2}{|c|}{ Technical Parameters } & JUSUR & JUMP \\
\hline \multirow{5}{*}{ Assessment Tools } & Assignment & $\checkmark$ & $\checkmark$ \\
\hline & Quiz & $\checkmark$ & $\checkmark$ \\
\hline & Survey / Poll & $\checkmark$ & $\checkmark$ \\
\hline & Team Project & $\checkmark$ & $\checkmark$ \\
\hline & Plagiarism Tool & $\mathrm{x}$ & $\checkmark$ \\
\hline \multirow{3}{*}{$\begin{array}{l}\text { Collaborative } \\
\text { Tools }\end{array}$} & Discussion Forum & $\checkmark$ & $\checkmark$ \\
\hline & Chatting & $\checkmark$ & $\checkmark$ \\
\hline & Student-Teacher Counseling & $\mathrm{x}$ & $\checkmark$ \\
\hline Mobile App & $\begin{array}{c}\text { Stand-alone Application for } \\
\text { Mobile Devices }\end{array}$ & $\mathrm{x}$ & $\checkmark$ \\
\hline \multirow{4}{*}{ System Integration } & $\begin{array}{c}\text { Short Messaging Service } \\
\text { (SMS) }\end{array}$ & $\mathrm{x}$ & $\checkmark$ \\
\hline & $\begin{array}{l}\text { University Registration } \\
\text { System Integration }\end{array}$ & $\mathrm{x}$ & $\checkmark$ \\
\hline & $\begin{array}{l}\text { University Portal Service } \\
\text { Integration }\end{array}$ & $\mathrm{x}$ & $\checkmark$ \\
\hline & E-Mail System Integration & $\begin{array}{c}\checkmark \\
\text { (Through Gmail } \\
\text { Services) }\end{array}$ & $\begin{array}{c}\breve{ } \\
\text { (Jazan University } \\
\text { Official) }\end{array}$ \\
\hline Virtual Class Tool & Virtual Class Tool & $\begin{array}{c}\check{ } \\
\text { (Blackboard } \\
\text { Interface) }\end{array}$ & $\begin{array}{c}\checkmark \\
\text { (Customized } \\
\text { Development) }\end{array}$ \\
\hline Content Developer & Content Authoring Tool & $\mathrm{x}$ & $\checkmark$ \\
\hline $\begin{array}{l}\text { Social Media } \\
\text { Integration }\end{array}$ & $\begin{array}{l}\text { Integration with Social } \\
\text { Media Sites and Portals }\end{array}$ & $\mathrm{x}$ & $\checkmark$ \\
\hline
\end{tabular}

\subsection{Introduction to JUSUR}

JUSUR is one of the key projects initiated and managed by the National Centre for eLearning and Distance learning (NCeL) in the Kingdom of Saudi Arabia for achieving its goal of empowering people through e-Learning in Lifelong Education using cutting edge technology. The system was launched by the NCeL based on the system of METEOR-OUMs, which is the Malaysian Open University LMS through an agreement between the Ministry of Higher Education (MoHE) in the Kingdom of Saudi Arabia and the Malaysian METEOR company (Amer Saleem, Flayyeh Elameer, and Rozhan M. Idrus, 2010). JUSUR provides an interactive learning experience using its various features to provide teaching staff and the students in Saudi Arabia Universities and other associated institutes. Currently, there are 20 
Universities including Government authorities that have a partnership with the NCeL for providing the eLearning system for their students and employees' training (NCeL, 2015). The list of the partners associated with the NCeL is presented in Table-2.

Table 2

NCeL Partner/Institute/Organization

\begin{tabular}{|c|l|l|}
\hline $\begin{array}{c}\text { Sr } \\
\text { No. }\end{array}$ & Name of Partner/Institute/Organization & \multicolumn{1}{|c|}{$\begin{array}{c}\text { Website Address } \\
\text { Partner/Institute/Organization }\end{array}$} \\
\hline 1 & King Saud University & http://ksu.edu.sa/ar/ \\
\hline 2 & Islamic University in Medinah & http://iu.edu.sa/ \\
\hline 3 & Taif University & http://www.tu.edu.sa/ \\
\hline 4 & Umm al-Qura University & https://uqu.edu.sa \\
\hline 5 & Qassim University & http://www.qu.edu.sa/Pages/Home.aspx \\
\hline 6 & Taiba University & http://www.taibahu.edu.sa/ \\
\hline 7 & Al Baha University & http://www.bu.edu.sa/ \\
\hline 8 & University of Hail & http://www.uoh.edu.sa/Pages/default.aspx \\
\hline 9 & Al Jauf University & http://www.ju.edu.sa/index.php?id=5 \\
\hline 10 & Al Imam Muhammad Ibn Saud Islamic & http://www.imamu.edu.sa/ \\
\hline 11 & University & King Fahd University of Petroleum \& \\
& Mineral Sciences & http://www.kfupm.edu.sa/default.aspx \\
\hline 12 & $\begin{array}{l}\text { Princess Nourah bint Abdulrahman } \\
\text { University }\end{array}$ & http://pnu.edu.sa/arr/Pages/default.aspx \\
\hline 13 & Jazan University & http://www.jazanu.edu.sa/Pages/Default.aspx \\
\hline 14 & Najran University & http://www.nu.edu.sa/gui/default.aspx?langid=1 \\
\hline 15 & Ministry of Interior & https://www.moi.gov.sa \\
\hline 16 & Ministry of Defense - 1 & http://www.msd.med.sa/ar/Pages/default.aspx \\
\hline 17 & Ministry of Defense - 2 & http://www.rsadf.gov.sa/ \\
\hline 18 & Imam Shatiby Institute for Quranic Studies & http://www.shatiby.edu.sa/ \\
\hline 19 & Human Resources Development Fund & https://www.hrdf.org.sa/ \\
\hline 20 & Majmaah University & https://www.mu.edu.sa/ \\
\hline
\end{tabular}

Like other academic institutions in the Kingdom of Saudi Arabia, Jazan University has also used the JUSUR platform as a Learning Management System for conducting the eLearning and distance learning programmes. Figure1 represents the JUSUR Portal page with its basic functions.

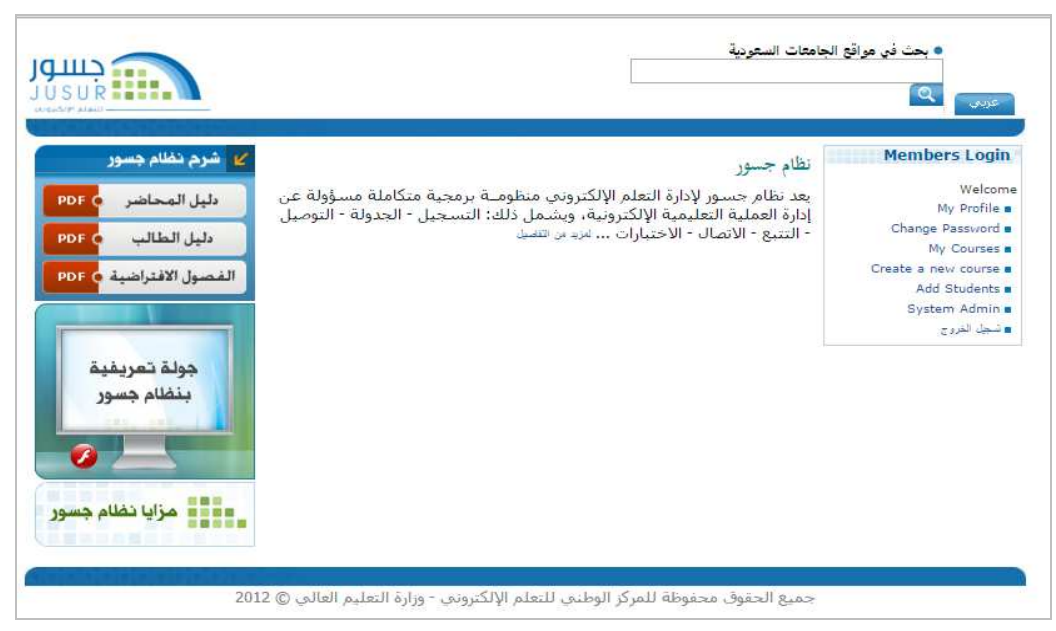

Figure 1. JUSUR Portal Page 


\subsection{Introduction to JUMP}

The need for developing and using the JUMP as a new LMS is to implement a broad range of e-learning programmes. Jazan University endeavors to achieve an academic perfection into producing a globalised online education. Figure 2 represents the JUMP Portal page with its basic functions.

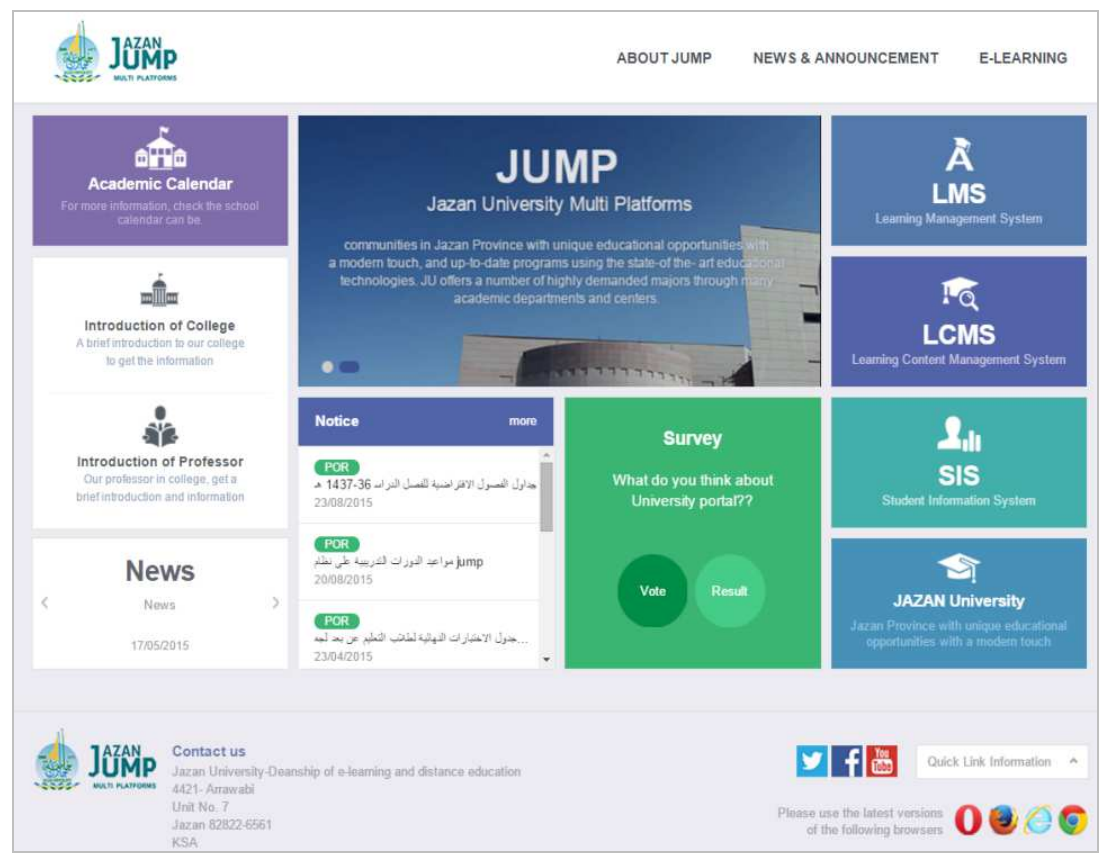

Figure 2. JUMP Portal Page

The intention is to develop an innovative e-learning programme to support the regularly growing number of students of the university who are beginning their university studies through online programmes. The University has taken advantage of this opportunity by implementing Online Education through advanced technology that can help Faculty and Students to provide and gain learning through the system, seamlessly. The core intention behind the JUMP is to make a transformation in using the eLearning system from a disintegrated system to a fully integrated one. Its purpose is to give an effective learning environment to the students and faculty by designing a total e-learning solution.

\section{JUMP SYSTEM PLATFORMS}

The JUMP provides an interracial environment through integrated components as mentioned in Figure 3. All of these components work together, which is essential for providing an effective and collaborative learning environment.

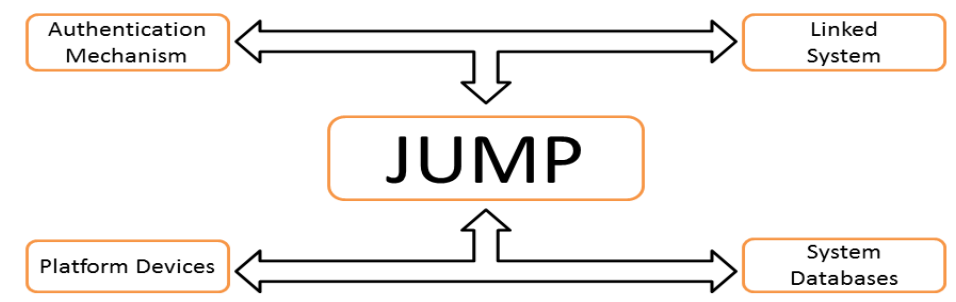

Figure 3. JUMP Integrated Core-Component Architecture 
- Authentication Mechanism: Due to the inadequacy of the Single sign-on (SSO) facility in the JUSUR, there is a need for a utility in the new LMS that can accommodate the SSO services. The new JUMP system provides the Single sign-on (SSO) facility to obtain access to all the modules inside the JUMP like the LMS, Learning Content Management System (LCMS), Student Information System (SIS), Portal Services, etc. The SSO gives an advantage to the Faculty and Students to take access control on one portal and access all the academic systems including the University mailing system (Microsoft Exchange), Short Messaging Service (SMS), Academic Registration (eRegistrar), Library System, etc.

- Linked System: The JUMP system is integrated with other currently working systems which are providing academic-related facilities for teachers and students. These systems comprise the Short Messaging Service (SMS), Library, Financial, and Registration systems. All the other merged systems can be accessed through the JUMP by SSO User authentication.

- System Database: A Learning Management System is responsible for managing different databases running in the JUMP or other associated systems. The JUMP system handles its own system databases for Data Backup, LMS, LCMS, Portal, and SIS, and it synchronises the database with other associated databases like the Financial and Registration records etc.

- Platform Devices: This component consists of the hardware and software interfaces for accessing the JUMP management system. The JUMP development has made it easy to gain access from multiple end user devices including PC, Laptop, Apple and Android platforms, etc.

\section{JUMP LEARNING AND SYSTEM MODULE}

There are many similarities amongst the naming schemes of Virtual Learning Environment, Learning Management System or Managed Learning Environment (Wikipedia, 2015). These terms are often used conversely with reference to defining learning models. In generalised terms, all of them are a web-based platform or application used to develop, elaborate, and manage the contents by teachers for knowledge delivery to learners. The JUMP as a multi-platform learning model consists of eight (08) sub-modules as illustrated in Figure 4.

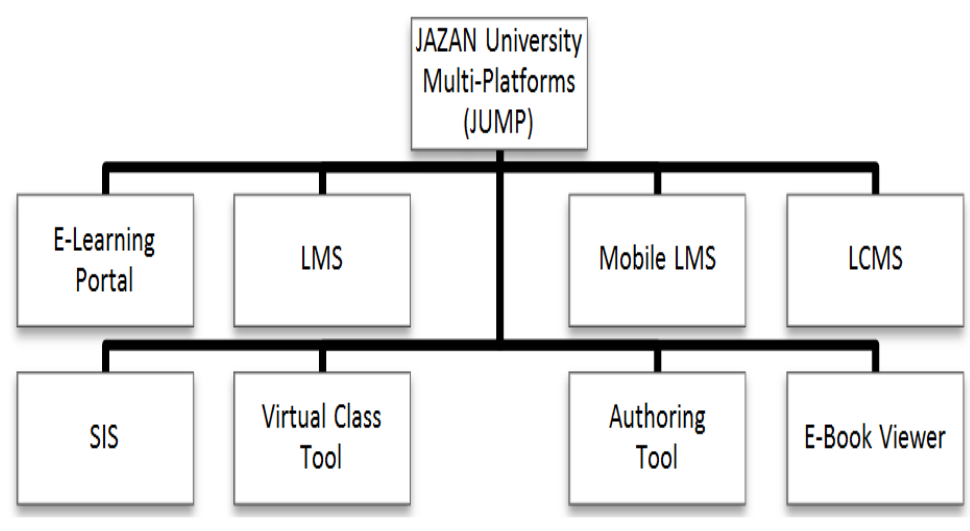

Figure 4. JUMP Core Modules

These modules of the JUMP system are responsible for development, assessment, and support of the system. The common requirement of the JUMP covers the package and 
solution customising, Multilingual operation, Islamic calendaring system, Browsing and operations support.

\subsection{E-Learning Portal}

The JUMP E-Learning portal is a Microsoft SharePoint-based deployment and acts like the main source of the system interface. The portal gives integration with the LMS, LCMS, SMS, and E-Mail linkages.

\subsection{Learning Management System (LCMS)}

The JUMP LMS provides a Virtual Learning Environment for delivering the online courses to Learners. This module contains the resources' repositories that can include Teaching Content, Files, Quiz material, Grade Management and Assessment, etc.

\subsection{Mobile LMS}

This module provides the learning's basic environment for mobile users. This module is responsible for seamless data synchronisation with the LMS. The Mobile LMS gives users an integrated view for mobile learning through mobile device resources' management and push notifications for mobile learning. The Mobile LMS manages the learning progress and accomplishment of each student.

\subsection{Learning Content Management System (LCMS)}

The LCMS is an incorporated module with the LMS that creates a multi-user environment for authoring, managing, distributing, and sharing the learning content amongst the tutors and learners. The LCMS module of the JUMP maintains the learning resource, package, category, template $\&$ user authorization management module. It also provides Internal/External application interfaces for the LMS, SIS, Virtual Class, Authoring Tool, and Social Network services. In this way, the JUMP LCMS seems more like a hybrid module as it holds managing features (like LMS) as well as the content databases.

\subsection{Student Information System (SIS)}

The SIS module provides the flexibility of accessing the current e-Register system services of Jazan University to be used through the JUMP interface. Through the SIS module, students can receive present courses, course timing, and instructor details directly from the eRegister system. The SIS handles various queries like a query of a student's academic grade sheet, registration/scholarship data, lesson and counselling history, previous certificate forms, and personal data management. Furthermore, the SIS module also provides the integration of the JUMP with the current campus-based SMS and e-Mail systems as well as outside campus social integration with Facebook, Twitter, etc.

\subsection{Virtual Class Tool}

This tool is a core module of the JUMP within which the Learner and Instructor can associate with each other. It provides integration with the LMC/LCMS, supports cross browsing, and audio/video transmission. The Virtual Class Tool supervises the online session and also provides the recording feature of the virtual class activities during the session along with the learning material sharing support. 


\subsection{Authoring Tool}

The Authoring tool module is used for developing the learning content for Personal Computers (PCs), Tablets, Notebooks, and Smart phones. It also provides the creation, editing, and import/export of the developed learning resources to and from the JUMP system. This tool works under a web browser installed at the user end without having to install any additional ActiveX controls or any other plug-in.

\subsection{E-Book Viewer}

The E-Book Viewer module provides the reading and accessibility features in the JUMP. The module is capable of ePUB and Multi-Platform support through the user's convenience to access the module on various system platforms including Laptops, PC's, Mobiles, etc. Through the E-Book viewer module, a Learner is able to view content based on the Reflow layout of ePUB's various versions.

\section{CONCLUSION AND FUTURE WORK}

The implementation of new systems and usage of new technologies in teaching and learning are now becoming the basic requirements for improving the learning cycle and, therefore, are beneficial for both the Faculty and Learners at educational institutions. The Jazan University, which is providing eLearning or Distance learning for its stakeholders, is progressively working by deploying the new LMS and enhancing the capabilities of their existing LMS through new technologie/s, skills, and tools for over the last couple of years. Although the new infrastructure has been deployed, it does not fully ensure the ideal environment for all of the Faculty and Student members of the Jazan University. There are various features that should be taken into consideration in order to produce an optimal eLearning and Distance education environment and eliminate the organisational, technological, and social barriers (Kristen S. B., 1998). In this paper, we have studied the key features and modules of the newly deployed LMS (JUMP) together with a technical module description available in the JUMP system accompanied by its integration with the further academic system and services successively being run at Jazan University. On the other hand, to develop an Ideal environment for Learning through the LMS and associated technologies, we will enhance our current research further and conduct a comprehensive survey with the Faculty and Students who have experienced the JUSUR and JUMP. This will result in the knowledge needed to judge the facilities and feedback for improving the Infrastructure or tools additionally required for a more enhanced learning experience.

\section{REFERENCES}

1. Schacter DL, Gilbert DT, Wegner DM. Psychology (2nd Edition) (2011). New York: Worth.

2. Muhammad A. and Muhammad N.S. (2014) "Emerging technologies for e-learning and distance learning: A survey. "IEEE-International Conference on Web and Open Access to Learning (ICWOAL).

3. Kenneth C. G, Cynthia G. (2013) "Campus Computing 2013: The national survey of e-learning and information technology in American higher education", Educause Annual Conference.

4. Doswell, Jayfus T. (2006) "Augmented learning: context-aware mobile augmented reality architecture for learning." IEEE- Sixth International Conference In Advanced Learning Technologies, pp. 1182-1183.

5. Amer S., Flayyeh E. and Rozhan M. I, (2010) The Readiness for an e- Learning System in the University of Mustansiriyah (UoMust) Baghdad-Iraq, Malaysian Journal of Educational Technology Volume 10, Number 2, pp. 31-41.

6. Retrieved from NCeL website as on 05 November 2015 (http://elc.edu.sa/?q=en/partners). 
7. Retrieved from Wikipedia from page on Managed Learning on November 05, 2015 (http://en.wikipedia.org/wiki/Managed_Learning_Environment).

8. Kristen S. B, (1998). An Institutional Overview: Factors Influencing Faculty Participation in Distance Education in Postsecondary Education in the United States: An Institutional Study, Published in Online Journal of Distance Learning Administration, Volume I, Number 3, Fall 1998 State University of West Georgia, Distance Education Center. Retrieved from http://www.westga.edu/ distance/betts13.html on 13th December 2016.

Text of the article was accepted by Editorial Team 24.10.2016

\title{
ОГЛЯД СИСТЕМИ УПРАВЛІННЯ ІНТЕРАКТИВНИМ НАВЧАННЯМ УНІВЕРСИТЕТУ ДЖАЗАН, САУДІВСЬКА АРАВІЯ
}

\author{
Халід Хуссейн К. Мукалі \\ доцент, декан факультету освіти \\ університет Джазан, Джазан, Королівство Саудівська Аравія \\ kmoukali@jazanu.edu.sa \\ Мухаммад Номан Саїд \\ викладач декан електронного і дистанційного навчання \\ університет Джазан, Джазан, Королівство Саудівська Аравія \\ msaeed@jazanu.edu.sa
}

\begin{abstract}
Анотація. Ефективне використання технологій сприяє створенню колабративного середовища, що вдосконалює традиційне дистанційне навчання. Попри це, їх використання викликає нову хвилю дискусій, до яких залучені різні учасники процесу, включаючи онлайн учнів, джерела навчання, а також менеджерів з електронного навчання. Система управління навчанням (СУН) визначається як концентратор (хаб) для обробки загальних рамок навчання в галузі дистанційної / електронної освіти. Система не тільки здатна охопити процес навчання для учнів, а й виступає як міст між учнями, викладачами і навчальними ресурсами. У цьому дослідженні описані основні характеристики і функції новітньої системи СУН, яка застосовується в університеті Джазан під назвою JUMP (Jazan University Multi-Platforms - мульти-платформи університету Джазан) з оглядом попередньої системи, JUSUR (JUSUR - арабське слово, що означає мости). Акцент на розгортанні JUMP, як нової системи управління навчанням, що витісняє попередню систему, зроблений з метою створення єдиної платформи електронного навчання для університету Джазан.
\end{abstract}

Ключові слова: електронне навчання; системи управління навчанням; JUMP; JUSUR; університет Джазан; дистанційне навчання.

\section{ОБЗОР СИСТЕМЫ УПРАВЛЕНИЯ ИНТЕРАКТИВНОГО ОБУЧЕНИЯ УНИВЕРСИТЕТА ДЖАЗАН, САУДОВСКАЯ АРАВИЯ}

\author{
Халид Хуссейн К. Мукали \\ доцент, декан факультета образования \\ университет Джазан, Джазан, Королевство Саудовская Аравия \\ Kmoukali@jazanu.edu.sa \\ Мухаммад Номан Саид \\ преподаватель, декан электронного и дистанционного обучения \\ университет Джазан, Джазан, Королевство Саудовская Аравия \\ msaeed@jazanu.edu.sa
}

Аннотация. Эффективное использование технологий способствует созданию колабративной среды, что совершенствует традиционное дистанционное обучение. Кроме того, их использование вызывает новую волну дискуссий, в которые вовлечены различные участники процесса, включая онлайн учеников, источники обучения, а также менеджеров 
по электронному обучению. Система управления обучением (СУН) определяется как концентратор (хаб) для обработки общих рамок обучения в области дистанционного / электронного образования. Система не только способна охватить процесс обучения для учащихся, но и выступает в качестве моста между учениками, преподавателями и учебными ресурсами. В данном исследовании описаны основные характеристики и функции новейшей системы СУН, которая применяется в университете Джазан под названием JUMP (Jazan University Multi-Platforms - мульти-платформы университета Джазан) с обзором предыдущей системы, JUSUR (JUSUR --арабское слово, означающее мосты). Акцент на развертывании JUMP, как новой системы управления обучением, вытесняя предыдущую систему, сделан с целью создания единой платформы электронного обучения для университета Джазан.

Ключевые слова: электронное обучение; системы управления обучением; JUMP; JUSUR; университет Джазан; дистанционное обучение.

\section{(c) $\mathrm{BY}-\mathrm{NC}-\mathrm{SA}$}

This work is licensed under Creative Commons Attribution-NonCommercial-ShareAlike 4.0 International License. 